ISSN 1392-3196 / e-ISSN 2335-8947

Zemdirbyste-Agriculture, vol. 104, No. 3 (2017), p. 219-228

DOI 10.13080/z-a.2017.104.028

\title{
Physiological response of plants to polyethylene glycol (PEG-6000) by exogenous melatonin application in wheat
}

\author{
Dongxiao LI, Di ZHANG, Hongguang WANG, Yanming LI, Ruiqi LI \\ Agricultural University of Hebei, \\ Key Laboratory of Crop Growth Regulation of Hebei Province \\ Baoding 071001, P. R. China \\ E-mail: lidongxiao.xiao@163.com
}

\begin{abstract}
The regulation effect of melatonin on water use efficiency of leaf and potential mechanisms related to phytohormone of leaf/root were investigated using two wheat (Triticum aestivum L.) cultivars with contrasting drought tolerance: drought-tolerant 'Hengguan35' (HG35) and growing in irrigated fields 'Jimai22'(JM22). Four treatments, including normal water treatment $(\mathrm{N}), 20 \%$ polyethylene glycol $(\mathrm{PEG})(\mathrm{P}), \mathrm{P}+1 \mu \mathrm{M}$ melatonin and $\mathrm{P}+10 \mu \mathrm{M}$ melatonin were conducted. Results indicated that exogenous melatonin could significantly improve net photosynthetic rate $(\mathrm{Pn})$, instantaneous water use efficiency $\left(\mathrm{WUE}_{\text {inst. }}\right)$ and intrinsic water use efficiency $\left(\mathrm{WUE}_{\text {intr. }}\right.$ ) of cultivar 'Jimai22'. This was possibly related to increasing root auxin (IAA), zeatin riboside (ZR) content and inhibiting abscisic acid (ABA), hydrogen peroxide $\left(\mathrm{H}_{2} \mathrm{O}_{2}\right)$ and aminocyclopropane-1-carboxylic acid (ACC) production in leaf. However, for cultivar 'Hengguan35', $1 \mu \mathrm{M}$ and $10 \mu \mathrm{M}$ melatonin did not improve photosynthetic rate and chlorophyll content even took negative effect on that. This could be caused by high vapour pressure deficit (VPD) and high $\mathrm{H}_{2} \mathrm{O}_{2}$ contents in leaf. Also, as a drought-tolerant cultivar, 'Hengguan35' possesses some physiological regulation itself such as increasing IAA and ZR content in root and leaf, inhibiting $\mathrm{H}_{2} \mathrm{O}_{2}$ production in root. But $\mathrm{ABA}$ and $\mathrm{ACC}$ content in root was not inhibited, even increased with melatonin under drought treatment. ACC was a potential central player in the hormone cross-talks that regulated leaf and root growth and physiological function. These results suggest that the effect of exogenous melatonin application on drought-resistance in seedling was distinct owing to wheat cultivars with different drought sensitivity, and this was also involved in complicated mechanism of physiological regulation to keep water status. Suitable application of melatonin thus can be an effective way in improving plant drought tolerance in wheat.
\end{abstract}

Key words: drought, melatonin, phytohormone, Triticum aestivum, water use efficiency.

\section{Introduction}

Drought stress represents one of the major limitations to winter wheat productivity by alleviating both leaf growth and photosynthetic capacity, which further limit the harvestable biomass and productivity. In the North China Plain, the rainfall during the entire growth stage in wheat is far below the actual water demand level (Cao et al., 2003), which results in large decline of the groundwater resource and reduction of the irrigation area of winter wheat during past 20 years (Jia, Liu, 2002). Therefore, it is critical to improve the water use efficiency (WUE) in winter wheat production on which to promote the sustainable agriculture in North China (Guan et al., 2015).

Melatonin, a growth regulator identified in higher plants in 1995, has been reported successively on regulating various biological processes, including root formation (Zhang et al., 2014), flowering and fruit ripening (Shi et al., 2016), and leaf senescence (Wang et al., 2012 a). In particular, melatonin can trigger the plant defense responses against abiotic stress, playing an important role in improving the tolerance of plants to adverse environment (Li et al., 2012; Turk et al., 2014; Meng et al., 2015; Bałabusta et al., 2016). This has been proposed to be related to scavenging active oxygen, increment of root to stem ratio, delaying induced leaf senescence, up-regulating of anti-stress genes and so on (Wang et al., 2012 b; Weeda et al., 2014; Jiang, Zu, 2015; Li et al., 2015; Ye et al., 2015). Currently, melatonin has been shown to act as an interesting natural biostimulator in regulating field crop production (Arnao, HernándezRuiz, 2014; Ye et al., 2016). The same concentration of melatonin may exert different effect on different organs of crops. Exogenous application of $10 \mu \mathrm{M}$ melatonin was efficient and induced more and longer roots in Lupinus (Arnao, Hernández-Ruiz, 2007); however, the same concentration of melatonin was inhibitory for adventitious rooting in the commercial sweet cherry (Sarropoulou et al., 2012). In addition, seeds treated by melatonin could promote the seedling growth and seed production of maize, soybean, and cucumber (Janas et al., 2009; Zhang et al., 2013; Wei et al., 2015). Meng (2016) suggests that wheat seed priming with melatonin

Please use the following format when citing the article:

Li D., Zhang D., Wang H., Li Y., Li R. 2017. Physiological response of plants to polyethylene glycol (PEG-6000) by exogenous melatonin application in wheat. Zemdirbyste-Agriculture, 104 (3): 219-228 DOI 10.13080/z-a.2017.104.028 
could enhance the biomass and yield once plants suffered water stress during filling stage.

Thus far, although the melatonin function in regulating plant growth and abiotic stress responses has been elucidated, the effect of melatonin on water utilization and phytohormone metabolism under drought stress is still largely uncharacterized in wheat. In this study, through exogenous application of melatonin in two wheat cultivars with contrasting drought tolerance (sensitive JM22 and tolerant HG35 cultivars), we investigated the potential role of melatonin in regulation leaf WUE, phytohormone and $\mathrm{H}_{2} \mathrm{O}_{2}$ content in leaves and roots of wheat under drought treatment. Our results would elucidate the melatonin effects in mediating plant drought tolerance and provide a new strategy in improving drought resistance and water use in wheat production.

\section{Material and methods}

Study site and experiment description. The experiment was carried out in a phytotron, Agricultural University of Hebei, Baoding city, China in 20152016. The environmental data will be documented and controlled by the computer automatically. Growth temperature of day/night was set $22 / 8^{\circ} \mathrm{C}$; the length of day/night was $12 / 12 \mathrm{~h}$. Relative humility was $60 \%$.

Plant material and experimental practices. Two wheat (Triticum aestivum L.) cultivars including the drought-tolerant cultivar 'Hengguan35' (HG35) and the irrigated cultivar 'Jimai22' (JM22) were used in this study. The HG35 seeds were provided by Dry Land Farming Research Institute of Hebei Academy of Agricultural and Forestry Sciences, whereas the cultivar JM22 seeds were donated by Crop Research Institute, Shandong Academy of Agricultural Sciences. At first, wheat seeds were germinated in a holed tray fitted by moist vermiculite at $22^{\circ} \mathrm{C}$. After about three days, at the first leaf expansion stage, the seedlings were transferred into a plastic box (length $\times$ width $\times$ height $=19 \times 13.5 \times$ $7.5 \mathrm{~cm}$ ) that was filled with Hogland solution (Table 1). One-leaf seedlings were moved through holes and fixed with small flexible polyfoam in each hole drilled on a flat polyurethane foam. There were 6 wheat seedlings could be fixed on each foam, covering the top of plastic box. All sides of the containers were wrapped by blank and light-proof film. And, more remarkable, all roots of wheat seedlings should be submerged into growth

Table 1. Concentration of Hogland solution constituent

\begin{tabular}{ccc}
\hline \multicolumn{2}{c}{ Constituent } & $\begin{array}{c}\text { Concentration } \\
\mathrm{g} \mathrm{L}^{-1}\end{array}$ \\
\hline \multirow{3}{*}{ Macroelement } & $\mathrm{KH}_{2} \mathrm{PO}_{4}$ & 0.1360 \\
& $\mathrm{KNO}_{3}$ & 0.5050 \\
$\mathrm{MgSO}_{4} \times 7 \mathrm{H}_{2} \mathrm{O}$ & 0.4930 \\
\hline & $\mathrm{H}_{3} \mathrm{BO}_{3}$ & 2.8600 \\
Microelement & $\mathrm{MnCL}_{2} \times 4 \mathrm{H}_{2} \mathrm{O}$ & 1.8100 \\
$(1000 \times)$ & $\mathrm{ZnSO}_{4} \times 7 \mathrm{H}_{2} \mathrm{O}$ & 0.2200 \\
& $\mathrm{CuSO}_{4} \times 5 \mathrm{H}_{2} \mathrm{O}$ & 0.0800 \\
& $\mathrm{H}_{2} \mathrm{MoO}_{4}$ & 0.0180 \\
\hline $\mathrm{Ca}^{2+}$ & ${\mathrm{Ca}\left(\mathrm{NO}_{3}\right)_{2} \times 4 \mathrm{H}_{2} \mathrm{O}}_{1.1800}$ \\
\hline \multirow{2}{*}{$\mathrm{Fe}^{2+}$} & $\mathrm{FeSO}_{4} \times 7 \mathrm{H}_{2} \mathrm{O}$ & 0.0278 \\
& $\mathrm{Na}_{2} \mathrm{EDTA}_{2} \times 2 \mathrm{H}_{2} \mathrm{O}$ & 0.0373 \\
\hline
\end{tabular}

solution. Fresh culture solution was replaced every two days to avoid root anaerobic respiration. Fourteen days later, the plants were transferred into new culture solution to initiate four experimental treatments, including normal water treatment $(\mathrm{N}), 20 \%$ polyethylene glycol PEG6000 (P), 20\% PEG-6000 $+1 \mu \mathrm{M}$ melatonin $(\mathrm{P}+1 \mu \mathrm{M}$ melatonin), 20\% PEG-6000 $+10 \mu \mathrm{M}$ melatonin $(\mathrm{P}+$ $10 \mu \mathrm{M}$ melatonin). Three replications were performed for each treatment, and five measuring replications were performed on leaves with the same location from five different plants under each treatment. Four treatments were measured successively as 20\% PEG-6000 (P), $20 \% \mathrm{P}+1 \mu \mathrm{M}$ melatonin, 20\% $\mathrm{P}+10 \mu \mathrm{M}$ melatonin and $\mathrm{N}$ treatment. Both polyethylene glycol (PEG-6000) and melatonin were added into the culture solution. After processing for 12 hours, plants were measured and sampled under different treatments.

Measuring items and methods. Fully unfolded leaves were selected to measure the net photosynthetic rate $(\mathrm{Pn})$, stomatal conductance (gs), transpiration rate (Tr) and high vapour pressure deficit (VPD) using the portable photosynthesis system Li-6400 (LI-COR, USA). During measurements, the environmental conditions were as follows: $25 \pm 0.3^{\circ} \mathrm{C}, 400 \pm 5 \mathrm{~cm}^{3} \mathrm{~m}^{-3} \mathrm{CO}_{2}$ concentration and $1500 \mathrm{~mol} \mathrm{~m}^{-2} \mathrm{~s}^{-1}$ radiation intensity (Fenta et al., 2012).

SPAD (Soil and Plant Analyzer Development) value. This means the relative content of chlorophyll. Fully unfolded leaf (avoiding leaf vein) was selected and measured with a chlorophyll meter model SPAD-502 (Japan).

Water use efficiency (WUE) on leaf level was

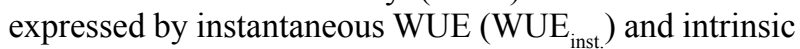
WUE ( $W_{U E} E_{\text {intr }}$ ), which were calculated from the ratio of Pn to Tr and the ratio of Pn to gs, respectively (Qiao et al., 2010).

Water potential. Fully unfolded leaf (avoiding leaf vein) was selected during midday conditions, and on each leaf we punched leaf discs with a hole puncher. Then, leaf discs were put into the closed leaf chamber of a potential meter WP4 Dewpoint (Decagon Devices Inc., USA) to measure water potential.

Phytohormone. Young leaves and roots $(0.5 \mathrm{~g})$ were sampled and then quickly frozen at $-80^{\circ} \mathrm{C}$. Then the samples were ground to homogenate with $5 \mathrm{~mL}$ $80 \%$ methyl alcohol (containing $1 \mathrm{mmol} \mathrm{L}^{-1}$ butylated hydroxytoluene) at $4^{\circ} \mathrm{C}$. After 4 hours' standing, the solution was centrifuged at $1000 \mathrm{~g}$ for $15 \mathrm{~min}$ (LDZ5-2, China). About $1 \mathrm{~mL}$ supernatant was transferred into centrifuge tube to concentrate and dry for $0.5 \mathrm{~h}$ with vacuum chamber (DZF-6020, China). Then the concentrated solution was centrifuged at $10000 \mathrm{r} \mathrm{min}^{-1}$ for $10 \mathrm{~min}$. Then the solution was leached by solid phase extraction C18 cartridges. The leached solution was transferred into $5 \mathrm{~mL}$ centrifuge tube and was blow-dried by $\mathrm{N}_{2}$ to evaporate methyl alcohol. Then the dry sample was diluted with phosphate buffer (containing $8.0 \mathrm{~g} \mathrm{NaCl}, 0.2$ $\mathrm{g} \mathrm{KH}_{2} \mathrm{PO}_{4}, 2.96 \mathrm{~g} \mathrm{Na}_{2} \mathrm{HPO}_{4} \times 12 \mathrm{H}_{2} \mathrm{O}, 1000 \mathrm{~mL}$ distilled water, $\mathrm{pH} 7.5$ ) to $2 \mathrm{~mL}$. (1) Prepared four 96-well plates $(8 \times 12)$ with four phytohormone antigens including auxin (IAA), zeatin riboside (ZR) content, gibberellin $\left(\mathrm{GA}_{3}\right)$ and abscisic acid (ABA). The first three lines were added $1000,500,250,125,62.5,31.25,15.625$ and 0 $\mathrm{ng} \mathrm{mL} \mathrm{mL}^{-1}$ phytohormone standard samples $50 \mu \mathrm{L}$ with three replicates poles of each concentration. Other poles were 
added sample solution $50 \mu \mathrm{L}$ with three replicate poles. (2) Then, added $50 \mu \mathrm{L}$ antibody into each pole for 0.5 $\mathrm{h}$ at $37^{\circ} \mathrm{C}$. (3) Washed the plates with phosphate buffer (including $1 \mathrm{~mL}$ Tween-20 per $1000 \mathrm{~mL}$ ) three times and added second antibody for $0.5 \mathrm{~h}$ at $37^{\circ} \mathrm{C}$. (4) Washed the plates again and added $100 \mu \mathrm{L}$ colour reagent $(15 \mathrm{mg}$ O-phenylenediamine; $10 \mathrm{~mL}$ substrate buffer solution: $5.10 \mathrm{~g} \mathrm{C}_{6} \mathrm{H}_{8} \mathrm{O}_{7} \times \mathrm{H}_{2} \mathrm{O}, 18.43 \mathrm{~g} \mathrm{Na}_{2} \mathrm{HPO}_{4} \times 12 \mathrm{H}_{2} \mathrm{O}$, $1000 \mathrm{~mL}$ distilled water and $1 \mathrm{~mL}$ Tween-20; $\mathrm{pH} 5.0$; $3 \mu \mathrm{L} 30 \% \mathrm{H}_{2} \mathrm{O}_{2}$ ). When the differential optical density (OD) value between 1000 and $0 \mathrm{ng} \mathrm{mL}^{-1}$ holes reached 1 , terminated the enzymatic reaction with $50 \mu \mathrm{L} 2 \mathrm{~mol} \mathrm{~L}^{-1}$ $\mathrm{H}_{2} \mathrm{SO}_{4}$ in each hole. Then absorbance was read at $492 \mathrm{~nm}$ using an indirect enzyme-linked immune absorption (ELISA) reader (BIO-RAD680, USA). The kit was provided by China Agricultural University. Logit curve tracing was adopted to calculate hormone content. The abscissa of logit curve was indicated by natural logarithm of standard phytohormone sample concentrations (ng $\mathrm{mL}^{-1}$ ); and the ordinate was indicated by the logit value of each colorimetric value at $492 \mathrm{~nm}$.

Aminocyclopropane-1-carboxylic acid (ACC) content. ACC content was determined based on the description of Yang (2014). Fresh leaves or root sampling $(0.1 \mathrm{~g})$ was ground to homogenate with $2 \mathrm{~mL} \mathrm{95 \%} \mathrm{ethyl}$ alcohol and placed in a hot water bath at $80^{\circ} \mathrm{C}$ for $15 \mathrm{~min}$. The solution was centrifuged twice at $8000 \times \mathrm{g}$ for $15 \mathrm{~min}$ ("Sigma centrifuges", UK). The supernatant was blowdried by $\mathrm{N}_{2}$, then diluted by $2 \mathrm{~mL} \mathrm{H}_{2} \mathrm{O}$. Then the diluents were added $2 \mathrm{~mL}$ trichloromethane to elute pigments. Finally $0.8 \mathrm{~mL}$ of the extracting solution was transferred into volume-known glass bottle. Then $0.2 \mathrm{~mL}, 3.3 \mathrm{mM}$ $\mathrm{HgCl}$ was injected into sealed $2 \mathrm{~mL}$ bottle, and mixture of $0.1 \mathrm{~mL} 5.5 \% \mathrm{NaOCl}$ and $\mathrm{NaOH}(\mathrm{v}: \mathrm{v}=2: 1)$ was added by injection syringe. After 5 min vibration the bottle on ice, $1 \mathrm{~mL}$ of gas was collected and subjected to assay of the ethylene contents using a gas chromatography (Agilent 7890B, USA).

Hydrogen peroxide $\left(\mathrm{H}_{2} \mathrm{O}_{2}\right)$ content. Fresh leaf and root samples $(0.5 \mathrm{~g})$ were measured based on the description of Prochazkova et al. (2001). Samples were homogenised in precool acetone $(1: 1)$ with a little quartz sand. The homogenate was centrifuged at $3000 \mathrm{r} \mathrm{min}^{-1}$ for $10 \mathrm{~min}$. The supernatant $(1 \mathrm{~mL})$ was mixed with $5 \%$ titanium sulphate and stronger ammonia water. The mixture was centrifuged at $3000 \mathrm{r} \mathrm{min}^{-1}$ for $10 \mathrm{~min}$ again. The precipitation was washed 3-5 times with acetone until pigment removed completely. Then the dissolved precipitation was mixed with $5 \mathrm{~mL}$ sulphuric acid $(2 \mathrm{~mol})$ and then diluted with water to $10 \mathrm{~mL}$. Absorbance was measured at $415 \mathrm{~nm}$ in an UV-visible spectrophotometer M 36 ("Beckman", USA).

Statistical analysis. All data were run using analysis of variance $(A N O V A)$ with three replicates according to Excel 2003 and SPSS 17.0. The Duncan's new multiple range (DMR) test at $5 \%$ probability level was used to test the differences among the mean values. Significant differences were labelled based on DMR.

\section{Results}

Photosynthetic indexes and water use efficiency on leaf level. The results of the experiment showed that for HG35, P treatment decreased significantly Pn, $\operatorname{Tr}$ and gs by 49.69, 91.71 and $94.44 \%$ with respect to $\mathrm{N}$, respectively. But it increased significantly the WUE $_{\text {inst. }}$ and $\mathrm{WUE}_{\text {intr. }}$ by 4.99 and 6.29 times compared with $\mathrm{N}$. $\mathrm{P}+1 \mu \mathrm{M}$ melatonin and $\mathrm{P}+10 \mu \mathrm{M}$ melatonin treatments reduced further the SPAD, Pn, WUE ${ }_{\text {inst. }}$ and $\mathrm{WUE}_{\text {intr. }}$ compared with $\mathrm{P}$ treatment. And the reduction of $\mathrm{P}+1 \mu \mathrm{M}$ melatonin was higher than $\mathrm{P}+10 \mu \mathrm{M}$ melatonin. This suggested that melatonin took no alleviation effect on photosynthesis of HG35 seedlings under drought stress. For JM22, P treatment decreased significantly $\mathrm{Pn}, \mathrm{Tr}$ and gs by $89.03,92.23$ and $90 \%$ compared with $\mathrm{N}$, respectively. WUE $\mathrm{W}_{\text {inst }}$ and $\mathrm{WUE}_{\text {int }}$ did not change significantly. However, compared with $P$, $\mathrm{P}+1 \mu \mathrm{M}$ melatonin significantly increased $\mathrm{Pn}, \mathrm{WUE}_{\text {inst. }}$ and $\mathrm{WUE}_{\text {intr }}$ by $1.81,1.84$ and 2.40 times, respectively. Meanwhile, $\mathrm{P}+10 \mu \mathrm{M}$ melatonin significantly increased SPAD, Pn, WUE inst. $_{\text {and }} \mathrm{WUE}_{\text {intr. }}$ increased by $12.42 \%$, 2.49 times, $66.13 \%$ and 1.21 times, respectively. This suggested that melatonin took obvious alleviation effect on photosynthesis and water utilization of JM22 seedlings under drought stress.

Water potential and vapour pressure deficit (VPD). The results of the experiment showed that water potential decreased significantly under drought condition compared with $\mathrm{N}$ for HG35 and JM22 (Fig. 1). Both P + $1 \mu \mathrm{M}$ and $\mathrm{P}+10 \mu \mathrm{M}$ melatonin treatments significantly improved this value under drought treatment. However, there were no significant differences between $\mathrm{N}$ and $\mathrm{P}+$ $10 \mu \mathrm{M}$ melatonin treatments. This suggested that $10 \mu \mathrm{M}$ melatonin could improve water potential upon plant exposure to drought treatment. VPD of HG35 showed

Table 2. Physiological effect of melatonin on SPAD, $\mathrm{Pn}\left(\mu \mathrm{mol} \mathrm{CO} \mathrm{m}^{-2} \mathrm{~s}^{-1}\right)$, $\mathrm{Tr}\left(\mathrm{mmol} \mathrm{H}_{2} \mathrm{O} \mathrm{m}^{-2} \mathrm{~s}^{-1}\right)$, gs $\left(\mathrm{mol} \mathrm{H}_{2} \mathrm{O} \mathrm{m}^{-2}\right.$ $\left.\mathrm{s}^{-1}\right), \mathrm{WUE}_{\text {inst. }}\left(\mu \mathrm{mol} \mathrm{CO} \mathrm{mmol} \mathrm{H}_{2} \mathrm{O}^{-1}\right), \mathrm{WUE}_{\text {intr. }}\left(\mu \mathrm{mol} \mathrm{CO} \mathrm{mol} \mathrm{H}_{2} \mathrm{O}^{-1}\right)$ of wheat leaf under drought treatment

\begin{tabular}{cccccccc}
\hline Cultivar & Treatment & SPAD & Pn & Tr & gs & WUE $_{\text {inst. }}$ & WUE $_{\text {intr. }}$ \\
\hline $\begin{array}{c}\text { 'Hengguan35' } \\
\text { (HG35) }\end{array}$ & Normal water treatment $(\mathrm{N})$ & $36.92 \mathrm{a}$ & $9.54 \mathrm{a}$ & $3.62 \mathrm{a}$ & $0.18 \mathrm{a}$ & $2.73 \mathrm{c}$ & $54.48 \mathrm{c}$ \\
& $20 \%$ PEG (P) & $37.1 \mathrm{a}$ & $4.74 \mathrm{~b}$ & $0.30 \mathrm{~b}$ & $0.01 \mathrm{c}$ & $16.35 \mathrm{a}$ & $397.04 \mathrm{a}$ \\
& $\mathrm{P}+1 \mu \mathrm{M}$ melatonin & $30.6 \mathrm{~b}$ & $2.24 \mathrm{c}$ & $0.28 \mathrm{~b}$ & $0.02 \mathrm{bc}$ & $8.04 \mathrm{~b}$ & $97.79 \mathrm{~b}$ \\
& $\mathrm{P}+10 \mu \mathrm{M}$ melatonin & $32.67 \mathrm{~b}$ & $1.01 \mathrm{~d}$ & $0.39 \mathrm{~b}$ & $0.02 \mathrm{~b}$ & $2.59 \mathrm{c}$ & $41.72 \mathrm{c}$ \\
'Jimai22' & Normal water treatment (N) & $41.25 \mathrm{ab}$ & $16.86 \mathrm{a}$ & $5.02 \mathrm{a}$ & $0.20 \mathrm{a}$ & $3.45 \mathrm{c}$ & $83.94 \mathrm{c}$ \\
(JM22) & $20 \%$ PEG (P) & $38.98 \mathrm{~b}$ & $1.85 \mathrm{~d}$ & $0.39 \mathrm{~b}$ & $0.02 \mathrm{~b}$ & $4.96 \mathrm{c}$ & $110.48 \mathrm{c}$ \\
& $\mathrm{P}+1 \mu \mathrm{M}$ melatonin & $38.92 \mathrm{~b}$ & $5.19 \mathrm{c}$ & $0.38 \mathrm{~b}$ & $0.01 \mathrm{~b}$ & $14.10 \mathrm{a}$ & $375.50 \mathrm{a}$ \\
& $\mathrm{P}+10 \mu \mathrm{M}$ melatonin & $43.82 \mathrm{a}$ & $6.45 \mathrm{~b}$ & $0.79 \mathrm{~b}$ & $0.03 \mathrm{~b}$ & $8.24 \mathrm{~b}$ & $244.66 \mathrm{~b}$ \\
\hline
\end{tabular}

Note. $\mathrm{Pn}$ - net photosynthetic rate, $\mathrm{Tr}$ - transpiration rate, gs - stomatal conductance, WUE $_{\text {inst }}$ - instantaneous, WUE intr $_{-}-$intrinsic $_{\text {inte }}$ water use efficiency; values followed by the same letter within each genotype are not significantly different at $P=0.05$ as determined by the Duncan's means comparison test. 

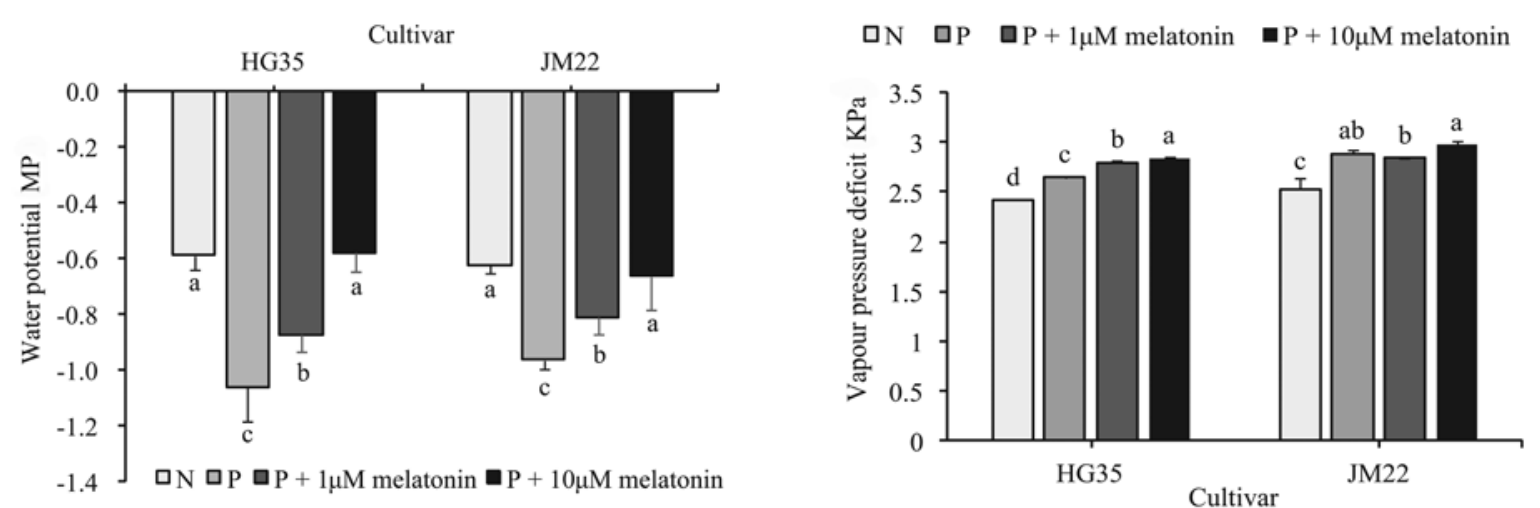

Note. Different letters indicate significant difference among treatments $(P<0.05)$.

Figure 1. Water potential and vapour pressure deficit of wheat leaves under normal water treatment (N), 20\% PEG (P), drought with $1 \mu \mathrm{M}(\mathrm{P}+1 \mu \mathrm{M}$ melatonin $)$ and $10 \mu \mathrm{M}(\mathrm{P}+10 \mu \mathrm{M}$ melatonin $)$ melatonin treatments

a significant increase under $\mathrm{P}, \mathrm{P}+1 \mu \mathrm{M}$ and $\mathrm{P}+10 \mu \mathrm{M}$ melatonin treatments compared with that under $\mathrm{N}$. This value of $\mathrm{P}+10 \mu \mathrm{M}$ melatonin was the highest. Likewise, VPD increased significantly in JM22 plants under P, $\mathrm{P}+1 \mu \mathrm{M}$ and $\mathrm{P}+10 \mu \mathrm{M}$ melatonin treatments compared with $\mathrm{N}$, but there were no significant differences between $\mathrm{P}$ and two concentrations of melatonin treatments. VPD of $\mathrm{P}+10 \mu \mathrm{M}$ was higher than that of $\mathrm{P}+1 \mu \mathrm{M}$ melatonin. It may be related to stomatal conductance changing under drought stress.

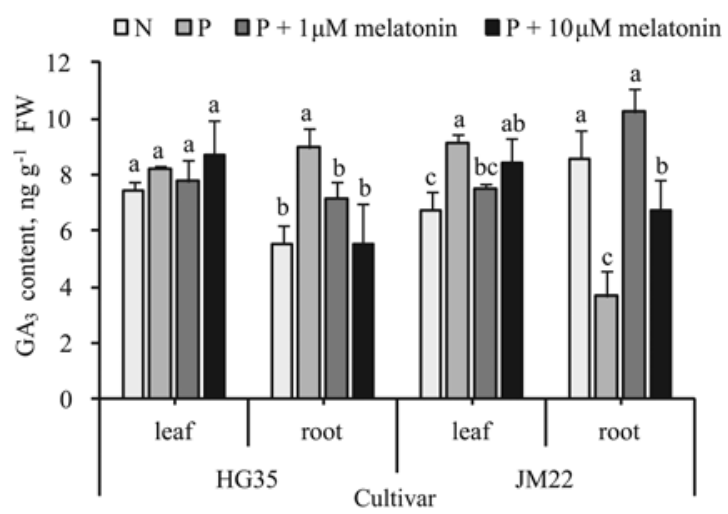

Gibberellin ( $\left.G A_{3}\right)$ and zeatin riboside $(Z R)$ content of leaf and root. For $\mathrm{HG} 35$, no obvious differences in $\mathrm{GA}_{3}$ content of leaf were seen among four treatments (Fig. 2). $\mathrm{GA}_{3}$ content in root under $\mathrm{P}$ increased significantly by $61.64 \%$ compared with $\mathrm{N}$; both $\mathrm{P}+1 \mu \mathrm{M}$ and $\mathrm{P}+10 \mu \mathrm{M}$ melatonin treatments did not change significantly. For JM 22, compared with $\mathrm{N}, \mathrm{GA}_{3}$ content of leaf under $\mathrm{P}$ and $\mathrm{P}+10 \mu \mathrm{M}$ melatonin treatments increased significantly by $35.54 \%$ and $25.04 \%$, respectively. However, the leaf $\mathrm{GA}_{3}$ content under $\mathrm{P}+1 \mu \mathrm{M}$ did not change obviously

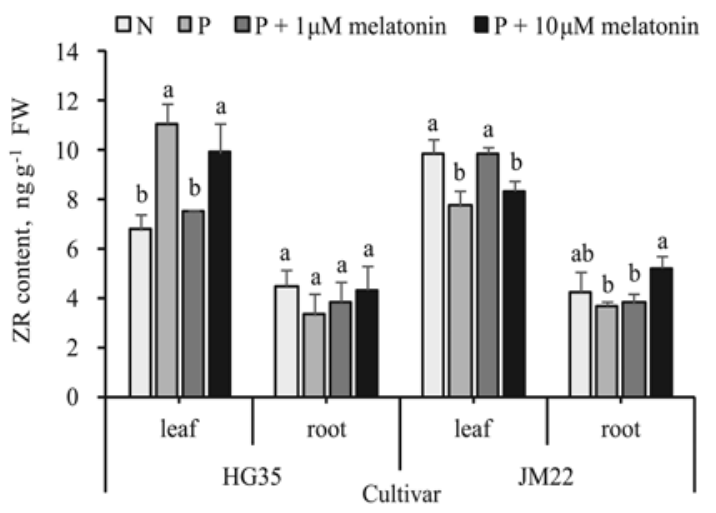

Note. Different letters indicate significant difference among treatments $(P<0.05)$.

Figure 2. Content of gibberellin $\left(\mathrm{GA}_{3}\right)$ and zeatin riboside $(\mathrm{ZR})$ in wheat leaf and root under normal water treatment $(\mathrm{N}), 20 \%$ PEG (P), 20\% PEG with $1 \mu \mathrm{M}(\mathrm{P}+1 \mu \mathrm{M}$ melatonin) and $10 \mu \mathrm{M}(\mathrm{P}+10 \mu \mathrm{M}$ melatonin) melatonin treatments

compared with N. Conversely, GA 3 contents of root under $\mathrm{P}$ and $\mathrm{P}+1 \mu \mathrm{M}$ melatonin treatments were decreased significantly by $57.33 \%$ and $21.82 \%$ relative to that of $\mathrm{N}$, respectively, whereas this value was similar under $\mathrm{P}+$ $10 \mu \mathrm{M}$ melatonin and $\mathrm{N}$ treatments.

Analysis on leaf ZR content revealed that it was higher than root ZR content. For HG35, compared with $\mathrm{N}$ treatment, ZR content of leaf under $\mathrm{P}$ and $\mathrm{P}+10 \mu \mathrm{M}$ melatonin treatments increased by $63.18 \%$ and $46.31 \%$, respectively; this value of root was changed little. Conversely, leaf ZR content in JM22 was significantly decreased under $\mathrm{P}$ and $\mathrm{P}+10 \mu \mathrm{M}$ melatonin treatments compared with that under $\mathrm{N}$, with decrease of $21.57 \%$ and $15.51 \%$, respectively. ZR content of root did not change significantly compared with $\mathrm{N}$; but this value under $\mathrm{P}+10 \mu \mathrm{M}$ melatonin treatment was significantly higher than $\mathrm{P}$ and $\mathrm{P}+1 \mu \mathrm{M}$ melatonin treatments. The results showed that $\mathrm{ZR}$ content was different in different organ and should take different effect.
Auxin (IAA) and abscisic acid (ABA) content of leaf and root. The data of the experiment showed that IAA content in leaf was higher than that in root (Fig. 3). For HG35, IAA content of leaf under $\mathrm{P}$ and $\mathrm{P}+10 \mu \mathrm{M}$ melatonin treatments were significantly higher than that under $\mathrm{N}$, with increase of $73.25 \%$ and $61.82 \%$, respectively. IAA content of root under $\mathrm{P}$ and $\mathrm{P}+10 \mu \mathrm{M}$ melatonin treatments increased significantly by $41.26 \%$ and $33.75 \%$. For JM22, no differences on leaf IAA content were seen among four treatments. Compared with $\mathrm{N}, \mathrm{P}$ significantly decreased root IAA content by $36.86 \%$; both $\mathrm{P}+1 \mu \mathrm{M}$ and $\mathrm{P}+10 \mu \mathrm{M}$ melatonin treatments did not change it evidently.

Obviously, ABA content in leaf was higher than that in root. For HG35, ABA content of leaf under $\mathrm{P}+10 \mu \mathrm{M}$ melatonin treatment decreased significantly by $18.01 \%$ compared with that under $\mathrm{N}$. In contrast, ABA contents of root under $\mathrm{P}+1 \mu \mathrm{M}$ and $\mathrm{P}+10 \mu \mathrm{M}$ 

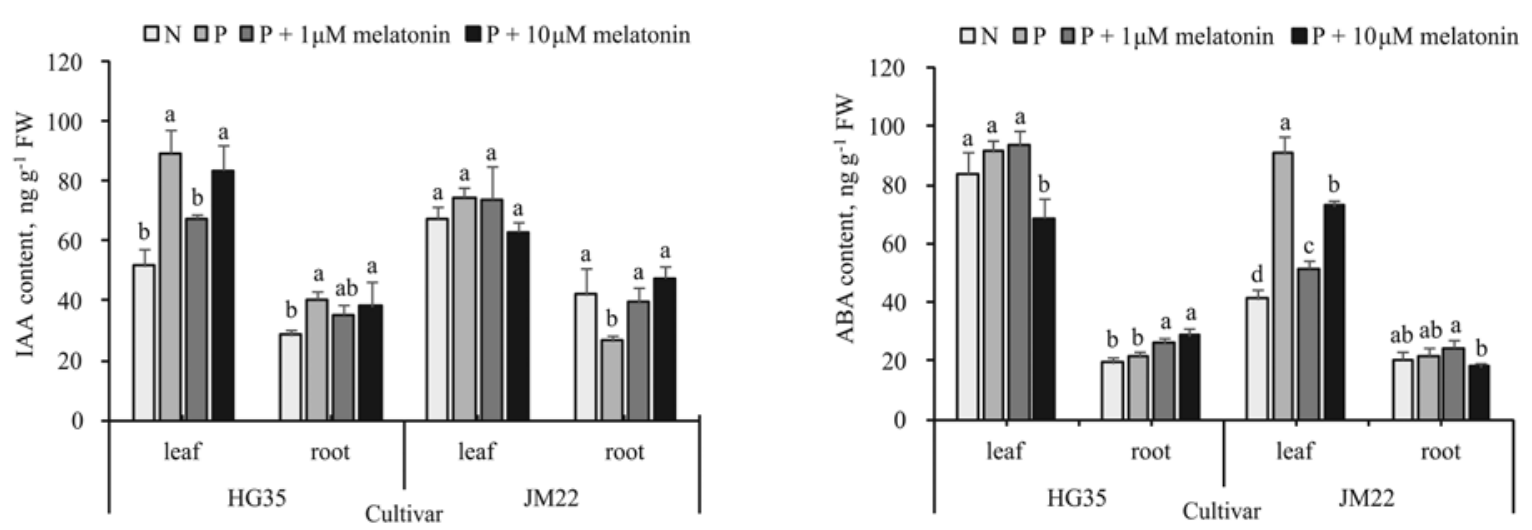

Note. Different letters indicate significant difference among treatments $(P<0.05)$.

Figure 3. Content of auxin (IAA) and abscisic acid (ABA) in wheat leaf and root under normal water treatment (N), $20 \%$ PEG (P), 20\% PEG with $1 \mu \mathrm{M}(\mathrm{P}+1 \mu \mathrm{M}$ melatonin) and $10 \mu \mathrm{M}$ melatonin $(\mathrm{P}+10 \mu \mathrm{M}$ melatonin) melatonin treatments

melatonin treatments increased significantly by $34.80 \%$ and $47.47 \%$, respectively. For JM22, compared with N, ABA content of leaf under $\mathrm{P}, \mathrm{P}+1 \mu \mathrm{M}$ melatonin and $\mathrm{P}+10 \mu \mathrm{M}$ melatonin treatments increased significantly by 1.21 times, $25.61 \%$ and $77.56 \%$, respectively. Root ABA content under $\mathrm{P}+10 \mu \mathrm{M}$ melatonin was significantly lower than that under $\mathrm{P}+1 \mu \mathrm{M}$ melatonin. No obvious differences were seen among other treatments.

Hormonal balance ratio. Hormone proportion could reflect action centre on different wheat organ under different treatments. For HG35, $\left(\mathrm{GA}_{3}+\mathrm{ZR}\right)$ /

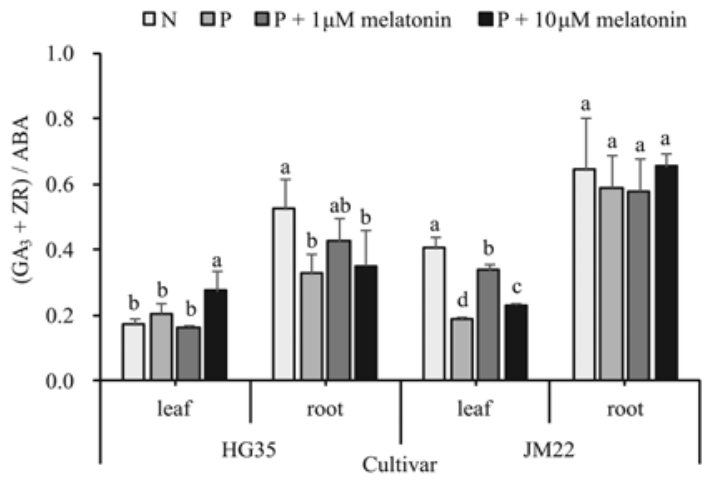

ABA of leaf under $\mathrm{P}+10 \mu \mathrm{M}$ melatonin treatment was significantly increased by $60.60 \%$ compared with $\mathrm{N}$ (Fig. 4). Conversely, $\left(\mathrm{GA}_{3}+\mathrm{ZR}\right) / \mathrm{ABA}$ of root was decreased under $\mathrm{P}$ and $\mathrm{P}+10 \mu \mathrm{M}$ melatonin treatments relative to that under $\mathrm{N}$, with reduction of $37.66 \%$ and $33.30 \%$, respectively (Fig. 4). This suggested that shoot growth had been inhibited in some extent. For JM22, compared with $\mathrm{N},\left(\mathrm{GA}_{3}+\mathrm{ZR}\right) / \mathrm{ABA}$ of leaf under $\mathrm{P}$, $\mathrm{P}+1 \mu \mathrm{M}$ and $\mathrm{P}+10 \mu \mathrm{M}$ melatonin treatments were all decreased by $53.91,16.53$ and $43.25 \%$, which suggested more ABA accumulation inducing stomatal closure.

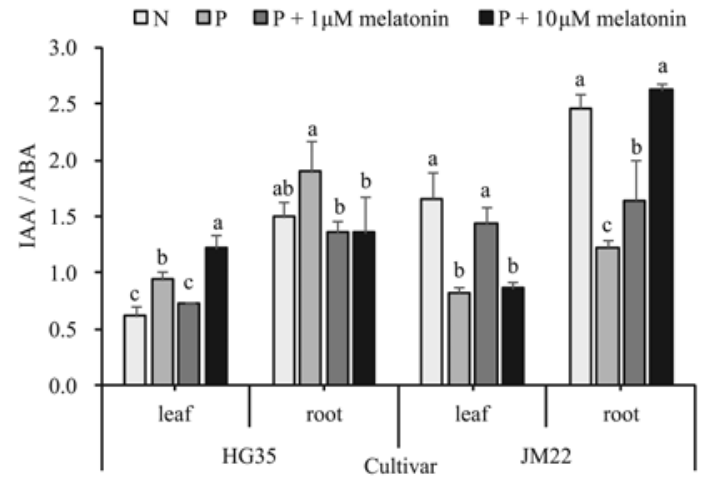

Note. Different letters indicate significant difference among treatments $(P<0.05)$.

Figure 4. Phytohormones proportion $\left(\mathrm{GA}_{3}+\mathrm{ZR}\right) / \mathrm{ABA}$ and IAA / ABA in wheat leaf and roots under normal water treatment $(\mathrm{N}), 20 \% \mathrm{PEG}(\mathrm{P}), 20 \% \mathrm{PEG}$ with $1 \mu \mathrm{M}(\mathrm{P}+1 \mu \mathrm{M}$ melatonin $)$ and $10 \mu \mathrm{M}(\mathrm{P}+10 \mu \mathrm{M}$ melatonin) melatonin treatments

Compared with N, IAA / ABA of leaf for HG35 under $\mathrm{P}$ and $\mathrm{P}+10 \mu \mathrm{M}$ melatonin treatments increased significantly by $51.70 \%$ and $96.96 \%$, respectively. This value of root under $\mathrm{P}+1 \mu \mathrm{M}$ and $\mathrm{P}+10 \mu \mathrm{M}$ melatonin treatments was significantly lower than that under $P$. For JM22, which was contrary to HG35, IAA / ABA of leaf under $\mathrm{P}$ and $\mathrm{P}+10 \mu \mathrm{M}$ melatonin treatments decreased significantly relative to $\mathrm{N}$ by $50.14 \%$ and $47.84 \%$, respectively. IAA / ABA of root was decreased significantly under $\mathrm{P}$ and $\mathrm{P}+1 \mu \mathrm{M}$ melatonin treatments compared with that under $\mathrm{N}$, with reduction of $50.10 \%$ and $66.70 \%$, respectively. This suggested central hormone was different due to different drought tolerance of two wheat cultivars and different concentrations of melatonin.

Aminocyclopropane-1-carboxylic acid (ACC) and hydrogen peroxide $\left(\mathrm{H}_{2} \mathrm{O}_{2}\right)$ contents. The data of the experiment showed that there were no significant differences in leaf ACC content of HG35 among four treatments (Fig. 5). Root ACC content of HG35 under P was higher significantly than that of $\mathrm{N}$. However, this value under $\mathrm{P}+1 \mu \mathrm{M}$ and $\mathrm{P}+10 \mu \mathrm{M}$ melatonin treatments was both decreased significantly compared with N. For JM22, leaf ACC content under $\mathrm{P}$ was significantly increased compared with N. No obvious changing was observed under both $\mathrm{P}+1 \mu \mathrm{M}$ and $\mathrm{P}+10 \mu \mathrm{M}$ melatonin treatments. The changing of root ACC contents in JM22 under four treatments was similar to that in HG35, namely, P increased this value significantly, but $\mathrm{P}+1 \mu \mathrm{M}$ and $\mathrm{P}+10 \mu \mathrm{M}$ melatonin treatments both decreased it significantly.

Drought stress significantly increased the $\mathrm{H}_{2} \mathrm{O}_{2}$ contents in roots of $\mathrm{HG} 35$ plants and in both leaves and roots of JM22 plants. Root $\mathrm{H}_{2} \mathrm{O}_{2}$ content of two cultivars 
口N $\square \mathrm{P} \quad \mathrm{P}+1 \mu \mathrm{M}$ melatonin $\mathbf{a} \mathrm{P}+10 \mu \mathrm{M}$ melatonin

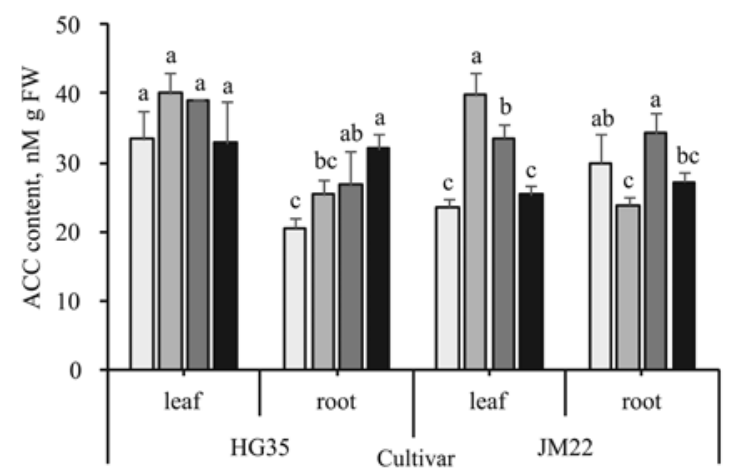

$\square \mathrm{N} \quad$ 口P $\quad \mathrm{P}+1 \mu \mathrm{M}$ melatonin

$\mathbf{P}+10 \mu \mathrm{M}$ melatonin

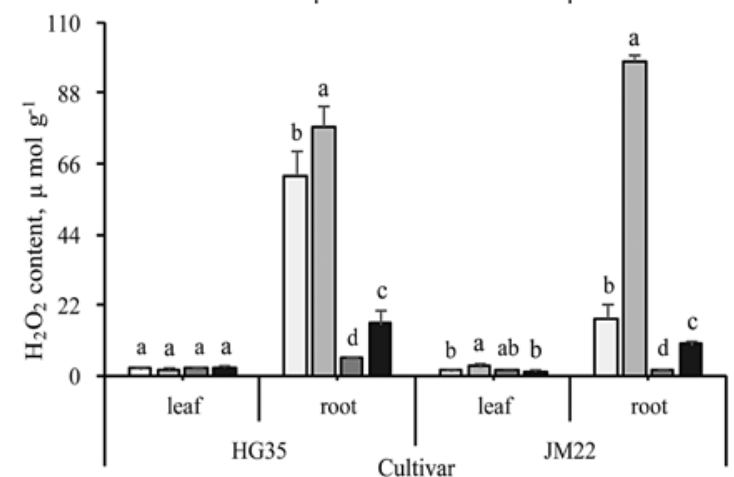

Note. Different letters indicate significant difference among treatments $(P<0.05)$.

Figure 5. Contents of aminocyclopropane-1-carboxylic acid (ACC) and hydrogen peroxide $\left(\mathrm{H}_{2} \mathrm{O}_{2}\right)$ in wheat leaves and roots under normal water treatment $(\mathrm{N}), 20 \%$ PEG $(\mathrm{P}), 20 \% \mathrm{PEG}$ with $1 \mu \mathrm{M}(\mathrm{P}+1 \mu \mathrm{M}$ melatonin) and $10 \mu \mathrm{M}$ $(\mathrm{P}+10 \mu \mathrm{M}$ melatonin) melatonin treatments

decreased significantly under both $\mathrm{P}+1 \mu \mathrm{M}$ and $\mathrm{P}+$ $10 \mu \mathrm{M}$ melatonin treatments compared with that under $\mathrm{N}$. And there were no significant differences in leaf $\mathrm{H}_{2} \mathrm{O}_{2}$ content of HG35 among four treatments.

Correlation analysis for phytohormones. The data of the experiment showed that ABA content was very significantly positively correlated with the ACC content $\left(\mathrm{n}=16, r=0.715^{* *}\right)$. Also, IAA content was very significantly positively correlated with ACC content ( $\mathrm{n}=16, r=0.632 * *)$. $\mathrm{GA}_{3}$ content was significantly positively correlated with ACC content $(\mathrm{n}=16$, $\left.r=0.503^{*}\right)$. However, there was no significant correlation between ACC and ZR content (Fig. 6).
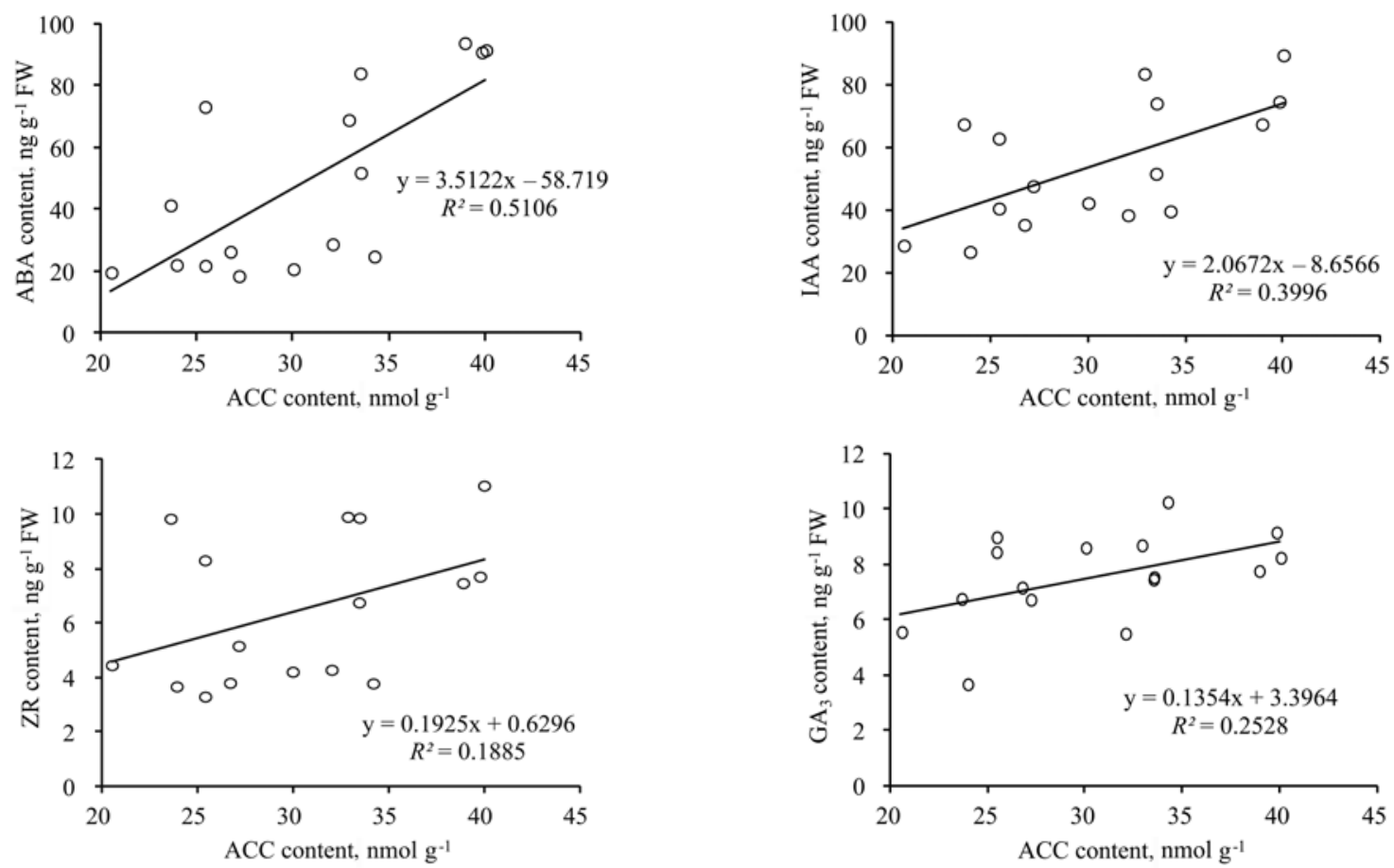

Figure 6. The correlation analysis of variance between aminocyclopropane-1-carboxylic (ACC) content and phytohormones-abscisic (ABA) acids, auxin (IAA), zeatin riboside (ZR), gibberellin $\left(\mathrm{GA}_{3}\right)$ contents

These results indicated that ACC was possible central player in the hormone cross-talks that regulated leaf and root growth and physiological function.

\section{Discussion}

Plants can alleviate the injury of drought stress by maximizing water uptake and/or minimizing water loss. Our study found that the leaf stomatal closure was induced by drought, given that the $\operatorname{Tr}$ and gs were drastically decreased under 20\% PEG (P) treatment. Meanwhile, Pn was also significantly decreased due to $\mathrm{CO}_{2}$ deficiency caused by lowered $\mathrm{Tr}$ and gs. However, WUE $\mathrm{Wnst}_{\text {ind }}$ and WUE $_{\text {intr. }}$, reflecting the leaf water status of plants, both showed an increasing trend under PEG condition. This result is consistent with that reported by Guo et al. (2010). Previous studies indicated that melatonin can improve chlorophyll content and photosynthetic character (Ye et al., 2016). In this research, we also found that melatonin could improve $\mathrm{Pn}, \mathrm{WUE}_{\text {inst. }}$ and $\mathrm{WUE}_{\text {intr. }}$ of the JM22 plants, suggesting its function in regulating the 
photosynthesis of wheat under drought. In addition, we also observed that the leaf water potential was decreased under drought significantly in two wheat cultivars, which could be recovered by both $1 \mu \mathrm{M}$ and $10 \mu \mathrm{M}$ melatonin. This finding may be attributed to stomatal closure and increasing VPD that reflect the evapotranspiration capacity of plant. However, exogenous application of melatonin did not exert positive roles on $\mathrm{Pn}$ and chlorophyll content in HG35 plants, which was possibly due to melatonin-mediated VPD elevation to lead to stomatal closure and photosynthesis decreasing (Xi et al., 2012). A large body of evidence have demonstrated that drought-induced growth limitation of crop was from hydraulic control in response to both soil water deficit and high VPD (Voisin et al., 2006; Tardieu et al., 2010). In this study, our results also indicated that drought increased VPD in two cultivars, in which HG35 showed much higher VPD under exogenous melatonin condition. The leaf and root $\mathrm{H}_{2} \mathrm{O}_{2}$ content are stimulated under drought and other abiotic stresses, which can damage cytomembrane and DNA and reduce plant growth and productivity. In our research, the leaf $\mathrm{H}_{2} \mathrm{O}_{2}$ contents of HG35 under both $\mathrm{P}+1 \mu \mathrm{M}$ and $\mathrm{P}+10^{2} \mu \mathrm{M}$ melatonin treatments did not decrease obviously; however, the root $\mathrm{H}_{2} \mathrm{O}_{2}$ contents of $\mathrm{HG} 35$ decreased significantly under the two melatonin treatments. Previous researches have also reported that melatonin could eliminate $\mathrm{H}_{2} \mathrm{O}_{2}$ content directly, protecting chlorophyll damage from the induced oxidative stress injury (Wang et al., 2012 a; Turk et al., 2014). For JM22, leaf and root $\mathrm{H}_{2} \mathrm{O}_{2}$ contents both decreased with $1 \mu \mathrm{M}$ and $10 \mu \mathrm{M}$ melatonin under drought treatment, which was consistent with the former conclusion. These findings together indicate that melatonin can improve plant growth and photosynthesis under drought conditions through effective alleviation of oxidative stress damage initiated by water stress.

Early studies reported that ABA can induce stomatal closure in various species regulated by $\mathrm{H}_{2} \mathrm{O}_{2}$ (Desikan, Neill, 2004; Bright et al., 2006; Miao et al., 2006; Seki, Urano, 2007). Exogenous melatonin application resulted in higher ABA concentration in drought-primed plants, suggesting that the interplay between melatonin and ABA improves water status under drought (Li et al., 2016). In this study, leaf ABA content in JM22 under P increased significantly, and decreased under $\mathrm{P}$ condition supplemented with $1 \mu \mathrm{M}$ melatonin and $10 \mu \mathrm{M}$ melatonin; root $\mathrm{ABA}$ content in JM22 under $\mathrm{P}+10 \mu \mathrm{M}$ melatonin was significantly decreased. In accordance with these findings, recent research has documented that melatonin can increase drought tolerance by enhancing ABA degradation and suppressing its synthesis. Consequently, less $\mathrm{H}_{2} \mathrm{O}_{2}$ is accumulated in the guard cells ( $\mathrm{Li}$ et al., 2015). Similar results have been reported that application of ABA to guard cells was shown to induce a burst of $\mathrm{H}_{2} \mathrm{O}_{2}$ that resulted in stomatal closure (Desikan, Neill, 2004). In this study, HG35 showed significantly decreased leaf ABA content under $\mathrm{P}+10 \mu \mathrm{M}$ melatonin treatment, but unreduced leaf $\mathrm{H}_{2} \mathrm{O}_{2}$ content; decreased root $\mathrm{H}_{2} \mathrm{O}_{2}$ content significantly, but significantly increased root $\mathrm{ABA}$ contents under $\mathrm{P}+$ $1 \mu \mathrm{M}$ and $\mathrm{P}+10 \mu \mathrm{M}$ melatonin treatments. This can be interpreted as drought tolerant cultivar HG35, cope with drought stress under melatonin treatments possibly through an ABA-dependent pathway. The detailed mechanism underlying this pathway regulated by melatonin needs to be further studied.
As known, melatonin and IAA have the same biosynthesis precursor, i.e. tryptophan, and melatonin could stimulate IAA biosynthesis by which to stimulate root growth (Chen et al., 2009). In this study, the leaf and root IAA content in HG35 plants were increased significantly under drought condition. Application of $1 \mu \mathrm{M}$ melatonin did not change it obviously comparing with $\mathrm{N}$ treatment, but $\mathrm{P}+10 \mu \mathrm{M}$ melatonin treatment was significantly higher than $\mathrm{N}$ treatment, which has no obvious differences with $\mathrm{P}$ treatment. This suggested that HG35 could regulate IAA content not by melatonin under drought condition. For JM22, root IAA content were decreased significantly under drought condition, but the reduced IAA contents could be recovered by application of $1 \mu \mathrm{M}$ and $10 \mu \mathrm{M}$ melatonin. This suggested that melatonin improved root drought-resistant. There were no differences on leaf IAA content were seen among four treatments. This was partly consistent with the result of exogenous application of $0.1 \mathrm{mM}$ melatonin also raised the endogenous levels of free IAA in roots, while higher concentrations had no significant effect (Chen et al., 2009). Therefore, the melatonin effects on regulating IAA accumulation needs to be further characterized.

Cytokinin ZR and the ethylene precursor ACC are both root-derived hormones. Soil drying can reduce the transport of cytokinins from root to shoot (Davies et al., 2005). Also, drought can increase the generation of ethylene in shoots by promoting root ACC synthesis and xylem transporting ACC to shoots (Sobeih et al., 2004). In this study, we found that ZR content in HG35 leaf was significantly higher under $\mathrm{P}$ and $\mathrm{P}+10 \mu \mathrm{M}$ melatonin treatments than those under $\mathrm{N}$ treatment. ACC content in leaf did not increase obviously under above treatments. This was attributed to higher drought-tolerance. Conversely, the leaf ZR content in JM22 were significantly lower under $\mathrm{P}$ and $\mathrm{P}+10 \mu \mathrm{M}$ melatonin treatments than those under $\mathrm{N}$ treatment; meanwhile, the ACC content was increased under $\mathrm{P}$ and $\mathrm{P}+1 \mu \mathrm{M}$ melatonin treatments. ZR content in root was significantly increased, and ACC content decreased significantly under $10 \mu \mathrm{M}$ melatonin treatment. These results showed that drought-inhibited ZR biosynthesis in wheat cultivars, especially in the drought sensitive ones, can be alleviated by exogenous melatonin. Correlation analysis showed that ACC possibly acted as the central player in regulating the hormone cross-talks under drought with melatonin application conditions.

All above have also indicated the effect of exogenous melatonin was tissue-selective in some extent. Cross-talk among different hormones from root to shoot would be influenced by external environment. In this study, melatonin had taken obvious inhibiting effect on root $\mathrm{H}_{2} \mathrm{O}_{2}$ content in $\mathrm{HG} 35$. The same concentration melatonin would promote growth in coleoptiles, but inhibit growth in roots (Hernández-Ruiz, Arnao, 2008 a; b). Drought also influenced dynamic equilibrium in endogenous hormone. In our study, IAA would take central effect for HG35, but ABA would take central effect for JM22 during drought regulation process due to different drought tolerances. Melatonin concentrations applied exert contrasting roles such as stimulatory effect or inhibitory one in different organs and wheat cultivars (Chen et al., 2009; Posmyk et al., 2009). In the present experiment, our results on different melatonin concentrations were also shown to be consistent with previous reports. The two wheat cultivars with contrasting 
drought tolerance under $10 \mu \mathrm{M}$ melatonin-exhibited improved growth under drought stress, suggesting that this melatonin concentration can be a useful index in improving plant growth under drought in wheat.

\section{Conclusion}

Our results indicated that exogenous melatonin can effectively improve the tolerance of wheat cultivar 'Jimai22' (JM22) to drought stress through its function in increasing net photosynthetic rate, water use efficiency on leaf by stomatal closure and water potential. 'Hengguan35' (HG35), as a drought-tolerant cultivar, exhibited relatively decreased net photosynthetic rate and transpiration rate under drought with $1 \mu \mathrm{M}$ and $10 \mu \mathrm{M}$ melatonin treatments compared with those under sole drought treatment. But this cultivar also showed some physiological regulation on increasing zeatin riboside (ZR), auxin (IAA) and inhibiting hydrogen peroxide $\left(\mathrm{H}_{2} \mathrm{O}_{2}\right)$ for the drought-primed plants. Application of suitable concentration of melatonin in wheat can be an effective strategy for improving plant drought stress tolerance and productivity. There is still lack of information to explain clearly the role of melatonin in physiology regulation for drought-tolerant wheat cultivar. More attention should be paid on increasing/decreasing melatonin concentration and respiratory pathway in root considering obvious inhibiting effect on hydrogen peroxide production.

\section{Acknowledgements}

This work was supported by the Chinese National Programs of Science and Technology for High Yielding Crop Production (2013BAD07B05). The Fund of Research Group Construction for Crop Science in Hebei Agricultural University (TD2016C317).

Received 16022017 Accepted 16062017

\section{References}

1. Arnao M. B., Hernández-Ruiz J. 2007. Melatonin promotes adventitious- and lateral root regeneration in etiolated hypocotyls of Lupinus albus L. Journal of Pineal Research, 42 (2): 147-152.

https://doi.org/10.1111/j.1600-079X.2006.00396.x

2. Arnao M. B., Hernández-Ruiz J. 2014. Melatonin: plant growth regulator and/or biostimulator during stress? Trends in Plant Science, 19 (12): 789-797.

https://doi.org/10.1016/j.tplants.2014.07.006

3. Bałabusta M., Szafrańska K., Posmyk M. M. 2016. Exogenous melatonin improves antioxidant defense in cucumber seeds (Cucumis sativus L.) germinated under chilling stress. Frontiers in Plant Science, 7: 575.

4. Bright J., Desikan R., Hancock J. T., Weir I. S., Neill S. J. 2006. ABA-induced $\mathrm{NO}$ generation and stomatal closure in Arabidopsis are dependent on $\mathrm{H}_{2} \mathrm{O}_{2}$ synthesis. Plant Journal, 45 (1): 113-122. https://doi.org/10.1111/j.1365-313X.2005.02615.x

5. Cao L., Dou Y. X., Zhang D.Y. 2003. Effect of climate change on ecological environment of heihe field. Arid Meteorology, 21 (4): 45-49.
6. Chen Q., Qi W. B., Reiter R. J., Wei W., Wang B. M. 2009. Exogenously applied melatonin stimulates root growth and raises endogenous indoleacetic acid in roots of etiolated seedlings of Brassica juncea. Journal of Plant Physiology, 166 (3): 324-328.

https://doi.org/10.1016/j.jplph.2008.06.002

7. Davies W. J., Kudoyarova G., Hartung W. 2005. Longdistance ABA signaling and its relation to other signaling pathways in the detection of soil drying and the mediation of the plant's response to drought. Journal of Plant Growth Regulation, 24 (4): 285-295.

https://doi.org/10.1007/s00344-005-0103-1

8. Desikan R., Neill S. J. 2004. ABA, hydrogen peroxide and nitric oxide signalling in stomatal guard cells. Journal of Experimental Botany, 55 (395): 205-212.

https://doi.org/10.1093/jxb/erh033

9. Fenta B. A., Driscoll S. P., Kunert K. J., Foyer C. H. 2012. Characterization of droughttolerance traits in nodulated soya beans: the importance of maintaining photosynthesis and shoot biomass under drought-induced limitations on nitrogen metabolism. Journal of Agronomy and Crop Science, 198 (2): 92-103.

https://doi.org/10.1111/j.1439-037X.2011.00491.x

10. Guan D., Zhang Y., Al-Kaisi M. M., Wang Q., Zhang M., Li Z. 2015. Tillage practices effect on root distribution and water use efficiency of winter wheat under rainfed condition in the North China Plain. Soil and Tillage Research, 146: 286-295.

https://doi.org/10.1016/j.still.2014.09.016

11. Guo X. Y., Zhang X. S., Huang Z. Y. 2010. Drought tolerance in three hybrid poplar clones submitted to different watering regimes. Journal of Plant Ecology, 3 (2): 79-87.

https://doi.org/10.1093/jpe/rtq007

12. Hernández-Ruiz J., Arnao M. B. 2008 (a). Distribution of melatonin in different zones of lupin and barley plants at different ages in the presence and absence of light. Journal of Agricultural and Food Chemistry, 56 (22): 10567-10573. https://doi.org/10.1021/jf8022063

13. Hernández-Ruiz J., Arnao M. B. 2008 (b). Melatonin stimulates the expansion of etiolated lupin cotyledons. Plant Growth Regulation, 55 (1): 29-34.

https://doi.org/10.1007/s10725-008-9254-y

14. Janas K. M., Ciupińska E., Posmyk M. M. 2009. Melatonin applied by hydropriming, as phytobiostimulator improving corn (Zea mays L.) seedlings growth at abiotic stresses conditions. Progress in Environmental Science and Technology, 2: 383-388.

15. Jia J. S., Liu C. M. 2002. Groundwater dynamic drift and response to different exploitation in the North China plain: a case study of Luancheng County, Hebei Province. Acta Geographica Sinica, 57: 201-209.

16. Jiang C. Q., Zu C. L. 2015. Advances in melatonin and its roles in abiotic stress resistance in plants. Biotechnology Bulletin: 31 (4): 47-55.

17. Li C., Wang P., Wei Z., Liang D., Liu C., Yin L., Jia D., Fu M., Ma F. 2012. The mitigation effects of exogenous melatonin on salinity-induced stress in Malus hupehensis. Journal of Pineal Research, 53 (3): 298-306. https://doi.org/10.1111/j.1600-079X.2012.00999.x

18. Li C., Tan D. X., Liang D., Chang C., Jia D., Ma F. 2015. Melatonin mediates the regulation of ABA metabolism, free-radical scavenging, and stomatal behaviour in two Malus species under drought stress. Journal of Experimental Botany, 66 (3): 669. https://doi.org/10.1093/jxb/eru476 
19. Li X., Tan D. X., Jiang D., Liu F. 2016. Melatonin enhances cold tolerance in drought-primed wild-type and abscisic acid-deficient mutant barley. Journal of Pineal Research, 61 (3): 328-339.

https://doi.org/10.1111/jpi.12350

20. Meng X. P. 2016. Effects of melatonin priming seedlings treatment on growth and physiology of wheat under water stress. Northwest A\&F University, Shaanxi, China (in Chinese) http://cdmd.cnki.com.cn/Article/CDMD10712-1016157079.htm.

21. Meng J. F., Xu T. F., Wang Z. Z., Fang Y. L., Xi Z. M., Zhang Z. W. 2015. The ameliorative effects of exogenous melatonin on grape cuttings under water-deficient stress: antioxidant metabolites, leaf anatomy, and chloroplast morphology. Journal of Pineal Research, 57 (2): 200-212. https://doi.org/10.1111/jpi.12159

22. Miao Y., Dong L., Wang P., Wang X. C., Jia C., Chen M., Song C. P. 2006. An arabidopsis alutathione peroxidase functions as both a redox transducer and a scavenger in abscisic acid and drought stress responses. The Plant Cell, 18 (10): 2749-2766. https://doi.org/10.1105/tpc.106.044230

23. Posmyk M. M., Bałabusta M., Wieczorek M., Sliwinska E., Janas K. M. 2009. Melatonin applied to cucumber (Cucumis sativus L.) seeds improves germination during chilling stress. Journal of Pineal Research, 46 (2): 214-223. https://doi.org/10.1111/j.1600-079X.2008.00652.x

24. Prochazkova D., Sairam R. K., Srivastava G. C., Singh D. V. 2001. Oxidative stress and antioxidant activity as the basis of senescence in maize leaves. Plant Science, 161 (4): 765-771. https://doi.org/10.1016/S0168-9452(01)00462-9

25. Qiao Y. Z., Zhang H. Z., Dong B. D., Shi C. H., Li Y. X., Zhai H. M., Liu M. Y. 2010. Effects of elevated $\mathrm{CO}_{2}$ concentration on growth and water use efficiency of winter wheat under two soil water regimes. Agricultural Water Management, 97 (11): 1742-1748.

https://doi.org/10.1016/j.agwat.2010.06.007

26. Sarropoulou V. N., Therios I. N., Dimassitheriou K. N. 2012. Melatonin promotes adventitious root regeneration in in vitro shoot tip explants of the commercial sweet cherry rootstocks CAB-6P (Prunus cerasus L.), Gisela 6 (P. cerasus $\times P$. canescens $)$, and $\mathrm{M} \times \mathrm{M} 60(P$. avium $\times$ P. mahaleb $)$. Journal of Pineal Research, 52 (1): 38-46. https://doi.org/10.1111/j.1600-079X.2011.00914.x

27. Seki M., Urano K. 2007. Regulatory metabolic networks in drought stress responses. Current Opinion in Plant Biology, 10 (3): 296-302. https://doi.org/10.1016/j.pbi.2007.04.014

28. Shi H., Wei Y., Wang Q., Reiter R. J., He C. 2016. Melatonin mediates the stabilization of DELLA proteins to repress the floral transition in Arabidopsis. Journal of Pineal Research, 60 (3): 373-379.

https://doi.org/10.1111/jpi.12320

29. Sobeih W. Y., Dodd I. C., Bacon M. A., Grierson D., Davies W. J. 2004. Long-distance signals regulating stomatal conductance and leaf growth in tomato (Lycopersicon esculentum) plants subjected to partial root-zone drying. Journal of Experimental Botany, 55 (407): 2353-2363. https://doi.org/10.1093/jxb/erh204

30. Tardieu F., Parent B., Simonneau T. 2010. Control of leaf growth by abscisic acid: hydraulic or non-hydraulic processes? Plant, Cell and Environment, 33 (4): 636-647. https://doi.org/10.1111/j.1365-3040.2009.02091.x
31. Turk H., Erdal S., Genisel M., Atici O. 2014. The regulatory effect of melatonin on physiological, biochemical and molecular parameters in cold-stressed wheat seedlings. Plant Growth Regulation, 74 (2): 139-152. https://doi.org/10.1007/s10725-014-9905-0

32. Voisin A. S., Reidy B., Parent B., Rolland G., Redondo E., Gerentes D., Tardieu F., Muller B. 2006. Are ABA, ethylene or their interaction involved in the response of leaf growth to soil water deficit? An analysis using naturally occurring variation or genetic transformation of ABA production in maize. Plant, Cell and Environment, 29 (9): 1829-1840. https://doi.org/10.1111/j.1365-3040.2006.01560.x

33. Wang P., Sun X., Li C., Wei Z., Liang D., Ma F. 2012 (a). Long-term exogenous application of melatonin delays drought-induced leaf senescence in apple. Journal of Pineal Research, 54 (3): 292-302. https://doi.org/10.1111/jpi.12017

34. Wang P., Yin L., Liang D., Li C., Ma F., Yue Z. 2012 (b). Delayed senescence of apple leaves by exogenous melatonin treatment: toward regulating the ascorbate-glutathione cycle. Journal of Pineal Research, 53 (1): 11-20. https://doi.org/10.1111/j.1600-079X.2011.00966.x

35. Weeda S., Zhang N., Zhao X., Ndip G., Guo Y., Buck G. A., Fu C., Ren S. 2014. Arabidopsis transcriptome analysis reveals key roles of melatonin in plant defense systems. PLoS ONE, 9 (3): 1-18. https://doi.org/10.1371/journal.pone.0093462

36. Wei W., Li Q.T., Chu Y. N., Reiter R. J., Yu X. M., Zhu D. H., Zhang W. K., Ma B., Lin Q., Zhang J. S. 2015. Melatonin enhances plant growth and abiotic stress tolerance in soybean plants. Journal of Experimental Botany, 66 (3): 695-707. https://doi.org/10.1093/jxb/eru392

37. Xi X. X., Tian Y. L., He Y. H. 2012. Photosynthetic characteristics of Ostryopsis davidiana Decaisne and relationship with influencing factor. Journal of Inner Monggolia Agricultural University, 33 (4): 81-86.

38. Yang W.B. 2014. Polyamines and ethylene biosynthesis in response to water deficit in wheat and its relations to grain filling. Shandong Agricultural University. http://cdmd.cnki. com.cn/Article/CDMD-10434-1014341837.htm

39. Ye J., Deng X. P., Wang S. Y., Yin L. N., Xiong B. L., Wang X. Y. 2015. Effects of melatonin on growth, photosynthetic characteristics and antioystem in seedling of wheat under droug ht stress. Journal of Triticeae Crops, 35 (9): 1275-1283.

40. Ye J., Wang S., Deng X., Yin L., Xiong B., Wang X. 2016. Melatonin increased maize (Zea mays L.) seedling drought tolerance by alleviating drought-induced photosynthetic inhibition and oxidative damage. Acta Physiologiae Plantarum, 38 (2): 48. https://doi.org/10.1007/s11738-015-2045-y

41. Zhang N., Zhao B., Zhang H. J., Weeda S., Yang C., Yang Z. C., Ren S., Guo Y. D. 2013. Melatonin promotes water-stress tolerance, lateral root formation, and seed germination in cucumber (Cucumis sativus L.). Journal of Pineal Research, 54 (1): 15-23.

https://doi.org/10.1111/j.1600-079X.2012.01015.X

42. Zhang N., Zhang H. J., Zhao B., Sun Q. Q., Cao Y. Y., Li R., Wu X. X., Weeda S., Li L., Ren S. 2014. The RNAseq approach to discriminate gene expression profiles in response to melatonin on cucumber lateral root formation. Journal of Pineal Research, 56 (1): 39-50. https://doi.org/10.1111/jpi.12095 
ISSN 1392-3196 / e-ISSN 2335-8947

Zemdirbyste-Agriculture, vol. 104, No. 3 (2017), p. 219-228

DOI $10.13080 / \mathrm{z}-\mathrm{a} .2017 .104 .028$

\title{
Kviečių fiziologinė reakcija ị polietilenglikolị (PEG-6000) egzogeniškai taikant melatoniną
}

\author{
D. Li, D. Zhang, H. Wang, Y. Li, R. Li \\ Hebei žemès ūkio universitetas \\ Hebei provincijos Pagrindinè augalų augimo reguliavimo laboratorija, Kinija
}

\section{Santrauka}

Siekiant nustatyti melatonino ir hormonų potencialų poveiki lapų vandens naudojimo efektyvumui, buvo pasirinktos dvi kviečių veislès, nevienodai atsparios sausrai: atspari 'Hengguan35' (HG35) ir auginama drèkinamuose laukuose 'Jimai22' (JM22). Tirti keturi daigų auginimo terpèje būdai: 1) mitybinèje terpèje (N), 2) $\mathrm{N}+20 \%$ polietilenglikolio $(\mathrm{PEG})(\mathrm{P}), 3) \mathrm{P}+1 \mu \mathrm{M}$ melatonino ir 4) $\mathrm{P}+10 \mu \mathrm{M}$ melatonino. Egzogeninis melatonimas esmingai padidino veislès JM22 grynosios fotosintezès intensyvumą (Pn), momentinị (WUE inst. $_{\text {) }}$ ir ịprastini (WUEintr.) vandens naudojimo efektyvumą. Tai galima sieti su šaknų didesnès koncentracijos auksinu (IAA) bei zeatino ribozidu (ZR) ir padidejusia lapų abscisinès rūgšties (ABA), vandenilio peroksido $\left(\mathrm{H}_{2} \mathrm{O}_{2}\right)$ bei aminociklopropan-1-karboksirūgšties (ACC) gamyba. Tačiau veislès HG35 fotosintezès greitis dèl $1 \mu \mathrm{M}$ ir $10 \mu \mathrm{M}$ melatonino nepadidejo, o chlorofilo koncentracija buvo netgi nepalanki. Taip galèjo būti dèl reikšmingai sumažèjusio vandens garų slėgio ir didelès vandenilio peroksido $\left(\mathrm{H}_{2} \mathrm{O}_{2}\right)$ koncentracijos lapuose. Be to, pasireiškè veislès HG35 fiziologinè savireguliacija, pvz., didejjo šios veislès kviečių šaknų bei lapų IAA ir ZR koncentracijos, buvo slopinama šaknų $\mathrm{H}_{2} \mathrm{O}_{2}$ gamyba. Naudojant melatoniną šaknų ABA ir ACC koncentracijos nesumažejo, o sausros sąlygomis net padidèjo. Sąveikaujant hormonams didžiausią reikšmę turi ACC, kuri valdo lapų bei šaknų augimą ir kitus fiziologinius reiškinius.

Tyrimo duomenimis, išlaikant ịprastinę vandens būklę išorinio melatonino poveikis daigams priklauso nuo kviečių veislès atsparumo sausrai ir sudètingos hormonų sąveikos. Taigi, melatoninas gali būti veiksminga priemonè siekiant pagerinti kviečių atsparumą sausrai.

Reikšminiai žodžiai: drègmės naudojimo efektyvumas, fitohormonas, melatoninas, sausra, Triticum aestivum. 